\title{
Fatty acids tracers for native and invasive macroalgae in an experimental food web
}

\author{
Jennifer R. Kelly*, Robert E. Scheibling, Sara J. Iverson \\ Department of Biology, Dalhousie University, Halifax, Nova Scotia B3H 4J1, Canada
}

\begin{abstract}
We assessed the potential of fatty acid (FA) markers for tracing primary production from an invasive green alga (Codium fragile ssp. fragile) and a native kelp (Saccharina longicruris) through 2 trophic levels in an experimental food web: a primary consumer, the green sea urchin Strongylocentrotus droebachiensis, and 2 secondary consumers, the native rock crab Cancer irroratus and invasive green crab Carcinus maenas. Sea urchins fed the 2 algal species had distinct gonadal FA compositions, and contained markers of each alga. Crabs of each species were then fed the gonads of sea urchins which had been fed either $S$. longicruris or $C$. fragile, and their hepatopancreases were analyzed. We were able to distinguish crabs of both species with $C$. fragile at the base of the food chain using the marker FAs 16:3n-3 and 18:3n-3. The overall FA composition of the hepatopancreas differed with diet in the green crab but not the rock crab. Our results suggest that 16:3n-3 may be a useful marker for tracing $C$. fragile production in grazers and some secondary consumers in rocky subtidal habitats in the Northwest Atlantic, but signal attenuation with each trophic transfer will limit the utility of this approach in higher consumers.
\end{abstract}

KEY WORDS: Fatty acid · Sea urchin $\cdot$ Crab $\cdot$ Macroalgae $\cdot$ Invasive species $\cdot$ Dietary tracer $\cdot$ Food web

\section{INTRODUCTION}

The development of dietary tracer techniques such as stable isotope (SI) and fatty acid (FA) analysis has enabled increasingly comprehensive studies of trophic relationships among marine organisms (Dalsgaard et al. 2003, Iverson et al. 2004, Budge et al. 2006, Rooker et al. 2006, Wai et al. 2008). Unlike analysis of gut contents or fecal pellets, these tracers can provide relatively long-term dietary data that are not biased toward food items with indigestible hard parts. Tracers may provide an additional advantage for studying food webs in that their signals may persist through multiple trophic transfers (Hall et al. 2006). Although both SI and FA analyses have been used effectively in studies of marine food webs, FAs may be preferable for delineating trophic relationships in some systems because they can provide finer resolution and more discriminatory power than SIs (Kharlamenko et al. 2001, Iverson et al. 2004, Rooker et al. 2006).
Marine primary producers, including bacteria, diatoms, dinoflagellates, angiosperms and macroalgae, can be distinguished by characteristic marker FAs, as well as combinations of FAs (Sargent et al. 1988, Graeve et al. 2002). These FAs are often conserved through trophic levels such that the FA patterns of consumers may be traced to their food sources (Graeve et al. 1994, Iverson et al. 1997). While quantitative transfer of whole combinations of FAs (the FA signature; Iverson 1993) has been clearly demonstrated near the top of food webs - i.e. from prey to vertebrate predators (Iverson et al. 2004, 2007) - this may be less likely at the base of food webs because of extensive FA biosynthesis and modification in invertebrate primary consumers. Nevertheless, FAs have been used to distinguish the sources of primary production consumed by grazers in a number of marine systems (Kharlamenko et al. 2001, Meziane et al. 2006, Rooker et al. 2006). In cases where a food source of interest is readily distinguishable based on the presence of a unique 
marker FA or an unusually large quantity of one or more FAs, it may be possible to trace primary producers through multiple trophic levels to higher-order consumers (Hall et al. 2006). Thus FA analysis may be particularly useful for elucidating the role of non-native algal species in the food webs of invaded ecosystems if the non-native species differ from native species in their overall FA composition or in their relative abundance of particular marker FAs.

The rocky subtidal ecosystem in Atlantic Canada presents an ideal model system for testing the transfer of FA markers across multiple trophic levels, and for tracking a non-native primary producer through a food web using FA analysis. Historically, this ecosystem has alternated between 2 states: kelp beds (mostly Saccharina longicruris and Laminaria digitata) with a low density of sea urchins Strongylocentrotus droebachiensis, and barren grounds dominated by sea urchins and encrusting coralline algae (Scheibling 1986). Facilitative interactions between recently introduced non-native species have brought about a third state of this ecosystem, in which an invasive green alga, Codium fragile ssp. fragile (previously C. fragile ssp. tomentosoides, Provan et al. 2008; hereafter C. fragile), has replaced kelp as the dominant canopy-forming macroalga off Nova Scotia and in the Gulf of Maine (Harris \& Tyrrell 2001, Chapman et al. 2002, Levin et al. 2002). The fate of $C$. fragile production is largely unknown, as it contains a chemical that may deter herbivores in the wild (Lyons et al. 2007, Lyons \& Scheibling 2008). Although sea urchins consume $C$. fragile in a single-diet situation, it is a low-preference food that supports a low level of gonad production compared to kelp (Prince \& LeBlanc 1992, Scheibling \& Anthony 2001, Sumi \& Scheibling 2005, Lyons \& Scheibling 2007a,b). FA analysis may be useful for revealing the role of $C$. fragile in nearshore rocky subtidal food webs by determining whether $C$. fragile is consumed by the dominant grazers and whether higher-order consumers prey on species that consume $C$. fragile.

Using FA signatures as dietary tracers in any system requires identification of FA markers in potential food species and controlled feeding experiments to determine whether these markers are conserved in the consumer (Budge et al. 2006, Hall et al. 2006). A few studies have used FAs to trace the transfer of organic matter from primary producers to invertebrate consumers in nearshore benthic ecosystems (Nichols et al. 1986, Kharlamenko et al. 2001, Alfaro et al. 2006, Meziane et al. 2006), and Hall et al. (2006) identified marker FAs that could be traced through 2 trophic transfers, from primary producer to secondary consumer, in a controlled feeding experiment. Sea urchins Strongylocentrotus droebachiensis fed different algal diets in the laboratory can be distinguished based on their gonadal FA signatures, but these do not resemble the FA signatures of their food because of their extensive de novo FA biosynthesis (Cook et al. 2000, Castell et al. 2004, Kelly et al. 2008). It may be possible, however, to distinguish the basal source of primary production in a multi-level food web including sea urchins by identifying markers of specific primary producers, or of sea urchins that consumed these primary producers, and finding these marker FAs in higher-order consumers. If FA markers can be used to distinguish organisms that use native kelp as their basal food source from those that use the non-native Codium fragile, this technique could be applied in field studies to compare the relative contribution of each species to higher trophic levels.

In the present study, we use FA analysis to trace 2 primary producers, non-native Codium fragile and native kelp Saccharina longicruris, through an experimental food web. We address the following specific questions: (1) Are there individual FA markers or characteristic FA ratios that can be used to track the fate of either algal species in grazers and higher-order consumers? (2) How does FA composition differ between sea urchins fed one or the other algal species? (3) How are the nutritional status and FA composition of the next trophic level (crabs fed sea urchins) affected by the source of primary production utilized by their prey?

\section{MATERIALS AND METHODS}

Experimental design. We constructed an experimental food web consisting of 3 trophic levels: (1) the native kelp Saccharina longicruris and the invasive green alga Codium fragile as primary producers; (2) the green sea urchin Strongylocentrotus droebachiensis as a herbivore that consumed either $S$. longicruris or C. fragile; and (3) the native rock crab Cancer irroratus and invasive green crab Carcinus maenas as predators that consumed sea urchins fed either $S$. longicruris or $C$. fragile. These species cooccur in shallow (<25 $\mathrm{m}$ depth) rocky habitats along the Atlantic coast of Nova Scotia and the Gulf of Maine (Harris \& Tyrrell 2001, Chapman et al. 2002, Levin et al. 2002). S. longicruris is a preferred food of sea urchins and supports high rates of their growth and reproduction (Scheibling \& Hatcher 2007). C. fragile is a low-preference food, although sea urchins consume it at high rates in the absence of kelps or other fleshy algae (Sumi \& Scheibling 2005, Lyons \& Scheibling $2007 b, 2008)$. Both crab species are generalist predators and scavengers. The rock crab commonly preys on sea urchins in the wild (Himmelman \& Steele 1971, Scheibling 1984), while the green crab typically does not (Scheibling \& Hamm 1991). 
Experimental organisms were collected using SCUBA at sites near Halifax, Nova Scotia. Saccharina longicruris was collected at Splitnose Point $\left(44^{\circ} 28^{\prime} \mathrm{N}\right.$, $63^{\circ} 32^{\prime} \mathrm{W}$ ) and Codium fragile at Cranberry Cove $\left(44^{\circ} 28^{\prime} \mathrm{N}, 63^{\circ} 56^{\prime} \mathrm{W}\right)$ as needed throughout the experiment. Algae were maintained in aquaria supplied with flowing seawater. Sea urchins were collected from a grazing front at the margin of the kelp bed at Splitnose Point in June and August 2007. Sea urchins were maintained in flowing seawater and fed ad libitum either S. longicruris or C. fragile. A total of 240 sea urchins collected in June were held in eight $75 \mathrm{l}$ glass aquaria (30 per aquarium) for $12 \mathrm{wk}$. By August, these sea urchins were beginning to show signs of stress (drooping spines, decreased feeding) associated with increasing water temperature $\left(17\right.$ to $18^{\circ} \mathrm{C}$; Lyons \& Scheibling 2007a). Therefore, we collected an additional 400 sea urchins and held them in 2 adjacent $1900 \mathrm{l}(150 \times 150 \times 85 \mathrm{~cm})$ fiberglass tanks with greater water flow and thermal buffering capacity. In October, remaining sea urchins from the 751 aquaria were transferred to the 1900-1 tanks. Uneaten algal rations in all tanks were removed and replaced with fresh algae twice per week. The change in wet weight of algae in each aquarium each week (11 June to 22 August 2007) was measured to calculate consumption rates.

Rock crabs and green crabs were collected at Duncan's Cove $\left(44^{\circ} 30^{\prime} \mathrm{N}, 63^{\circ} 31^{\prime} \mathrm{W}\right)$ in August 2007. Crabs were held without food in 4 fiberglass tanks supplied with flowing seawater for $1 \mathrm{wk}$ after collection. Individuals of both species were then allocated randomly to the 4 tanks (20 crabs per tank), and each diet (gonads of sea urchins fed either Saccharina longicruris or Codium fragile) was assigned randomly to 2 replicate tanks. Individual crabs were placed in plastic containers (1 1 volume), perforated (5 mm diameter holes) to allow water flow, within the tanks. Crabs were fed once per week for $14 \mathrm{wk}$ with $1 \mathrm{~g}$ of freshly dissected sea urchin gonad. Gonad tissue from $\geq 2$ sea urchins was fed to each crab at each feeding event, and we observed crabs until all sea urchin gonad tissue was consumed. From 28 August to 9 October, sea urchins from the $75 \mathrm{l}$ aquaria (which had been fed a single algal diet for a minimum of $12 \mathrm{wk}$ ) were used to feed crabs; thereafter, sea urchins from the larger tanks (which had been fed a single algal diet for a minimum of $10 \mathrm{wk}$ ) were used to feed crabs. Sea urchins were selected haphazardly for crab feeding and, because populations of Strongylocentrotus droebachiensis have a 1:1 sex ratio (Meidel \& Scheibling 1998), crabs likely consumed similar proportions of male and female sea urchin gonads.

Lipid extraction and FA analysis. Gonadal tissue was excised from 3 to 6 urchins from each algal diet on
28 August, 4 September, 17 October and 1, 15 and 28 November 2007. Hepatopancreases were excised from all crabs (euthanized by freezing) on 5 and 6 December 2007. To extract lipids from sea urchin gonads and crab hepatopancreas, a $1.5 \mathrm{~g}$ tissue sample from each animal was immediately transferred to a tube containing $20 \mathrm{ml}$ chloroform and $10 \mathrm{ml}$ methanol with $0.01 \%$ butylated hydroxytoluene (BHT) as an antioxidant. Tissue samples were manually homogenized, flushed with nitrogen and stored at $4^{\circ} \mathrm{C}$ for 24 to $48 \mathrm{~h}$ prior to lipid extraction. Algae were blotted to remove excess water and cleaned of epibionts before being chopped coarsely and manually homogenized using a mortar and pestle. A $9.0 \mathrm{~g}$ sample from each algal thallus ( $\mathrm{n}=5$ for each species) was weighed before adding $20 \mathrm{ml}$ chloroform and $10 \mathrm{ml}$ methanol with $0.01 \%$ BHT.

Lipid extraction protocols were modified from Folch et al. (1957) as described in Kelly et al. (2008). The samples in solvent (algae, sea urchin gonad or crab hepatopancreas) were filtered (Fisher P8 filter paper) to remove any tissue before adding $7 \mathrm{ml} 5 \% \mathrm{NaCl}$. Samples were shaken and then centrifuged for $20 \mathrm{~min}$. The lipid-containing lower phase was filtered through $\mathrm{NaSO}_{4}$ and evaporated to dryness under nitrogen at 25 to $30^{\circ} \mathrm{C}$ in a pre-weighed boiling tube. The boiling tube was re-weighed to calculate the amount of crude lipid for each sample.

Crude lipid samples were purified to remove proteins, pigments and cholesterol using thin-layer chromatography (TLC). Lipids were dissolved in hexane and spotted onto silica TLC plates (Sigma) and developed in a TLC chamber with a 90:10:1 petroleum ether:ethyl ether:acetic acid solution for approximately $45 \mathrm{~min}$. Plates were sprayed with 2,4 dichlorofluorescein and viewed under UV light to mark the lipidcontaining band. The lipid-containing band was then scraped from the silica plate and transferred to a funnel packed with silane-treated glass wool. Chloroform with $0.01 \%$ BHT was used to dissolve purified lipid into a pre-weighed tube. The sample was evaporated to dryness under nitrogen at 25 to $30^{\circ} \mathrm{C}$, and the purified lipid was dissolved in $1.5 \mathrm{ml}$ methylene chloride with $0.01 \%$ BHT and subjected to acidic transesterification $\left(\mathrm{H}_{2} \mathrm{SO}_{4}\right.$ in methanol) to produce FA methyl esters (FAME), as described in Budge et al. (2006). Following transesterification, hexane was added to a final concentration of $50 \mathrm{mg} \mathrm{ml}^{-1}$. Samples were stored at $-20^{\circ} \mathrm{C}$ prior to analysis. Duplicate samples of FAME were analyzed and FAs identified and quantified using temperature-programmed gas chromatography according to Iverson et al. $(1997,2004)$ and Budge et al. (2006). FAs are expressed as weight percent of total FAs and named as carbon number:number of double bonds and location (n-x) of the double bond nearest 
the terminal methyl group, where all additional double bonds are separated by a $-\mathrm{CH}_{2}$ - group (i.e. methyleneinterrupted). In non-methylene interrupted (NMI) FA, double bonds are separated by more than one methylene group and therefore named as each position $(\Delta)$ from the carboxyl end.

Statistical methods. Algal consumption rates, measured as the change in wet weight of algae in each aquarium each week (11 June to 22 August 2007) divided by the number of sea urchins in the aquarium, were compared between algal diets using repeatedmeasures ANOVA. Lipid content (\% wet weight) of the 2 algal species, and of gonads of sea urchins on the 2 algal diets, was compared using $t$-tests. Lipid content of algae and sea urchins and algal consumption data were homoscedastic ( $F$-ratio test, $\mathrm{p}>0.05)$. Lipid content of crab hepatopancreas tissue was compared between crab species and diet treatments using 2-way ANOVA. Crab lipid content data were heteroscedastic, so these were arcsine-transformed $\left(x^{\prime}=\sin ^{-1} \sqrt{ } x\right)$ to produce equal variances (Cochran's $Q, \mathrm{p}>0.05$ ).

Only FAs with an overall mean contribution $\geq 0.1 \%$ were used, and FA composition was standardized to $100 \%$ for all samples prior to analysis. Comparisons of overall FA composition were made using 1-way analysis of similarity (ANOSIM) and multidimensional scaling (MDS). ANOSIM and MDS were performed on Bray-Curtis distances (Clarke \& Warwick 1994) of untransformed data using PRIMER 6 software (Clarke \& Gorley 2006).

Levels of selected FAs were compared between algal species, between gonads of sea urchins on the 2 algal diets and between hepatopancreases of each crab species on the 2 sea urchin diets using $t$-tests with Bonferroni-adjusted p-values (experimentwise $\alpha=0.05$ ). The selection of these FAs was based on markers identified for Codium fragile (16:3n-3 and 18:3n-3; Khotimchenko 2003) and Saccharina longicruris (18:4n-3 and 20:4n-6; Cook et al. 2000). All FAs selected for pairwise comparisons were tested for homoscedasticity prior to performing $t$-tests ( $F$-ratio test, $\alpha=0.05$ ). Welch's $t$-test was used for data that did not meet the assumption of equal variances.

Levels of other FAs were compared across trophic levels; these FAs were selected based on known precursors for polyunsaturated FA (PUFA) synthesis (16:0, 18:0, 16:1n-7, 18:1n-9, 18:2n-6 and 18:3n-3; Dalsgaard et al. 2003). Individual FAs were compared between trophic levels using 2-way ANOVA with trophic level (algae vs. sea urchins, sea urchins vs. green crabs or red crabs) and primary production source (Saccharina longicruris or Codium fragile) as fixed factors. The total abundance of FAs found in sea urchins and crabs, but absent from algae, was compared between sea urchins on the 2 algal diets using a $t$-test, and between crabs using a 2-way ANOVA. These data were tested for homoscedasticity (Cochran's $Q, \alpha=0.05$ ); the arcsine transformation was used where it produced equal variances, but untransformed data were used where transformation did not improve homoscedasticity.

\section{RESULTS}

Lipid content of algae samples ranged from 0.23 to $0.93 \%$ wet weight in Saccharina longicruris and from 0.56 to $1.23 \%$ wet weight in Codium fragile, but the 2 species were not significantly different (Table 1 , Fig. 1). FA composition of $S$. longicruris differed significantly from that of $C$. fragile (ANOSIM, $\mathrm{p}=0.002$; Fig. 2a). Average Bray-Curtis dissimilarity between algal species was $42 \%$. C. fragile contained a significantly higher proportion of marker FAs 16:3n-3 and 18:3n-3 than did $S$. longicruris; $S$. longicruris contained

Table 1. Results of $t$-tests on relative abundance of fatty acid (FA) markers in organisms which differed in the source of primary production at their food web base (either Codium fragile ssp. tomentosoides or Saccharina longicruris). Precursor FA included 16:0, 16:1n-7, 18:0, 18:1n-9, 18:2n-6 and 18:3n-3. Sea urchin-synthesized FAs included 25 fatty acids present in sea urchin gonads but absent from their algal diets. ${ }^{*}$ Significant following Bonferroni correction (experimentwise $\alpha=0.05)$

\begin{tabular}{|c|c|c|c|}
\hline Variable & $\mathrm{df}$ & $t$ & $\mathrm{p}$ \\
\hline \multicolumn{4}{|l|}{ Algae } \\
\hline$\%$ lipid & 8 & 1.59 & 0.150 \\
\hline $16: 3 n-3$ & 4 & 12.33 & $0.000^{*}$ \\
\hline $18: 3 n-3$ & 5 & 12.07 & $0.000^{*}$ \\
\hline $18: 4 n-3$ & 5 & -6.58 & $0.001^{*}$ \\
\hline $20: 4 n-6$ & 4 & -9.06 & $0.001^{*}$ \\
\hline$\Sigma$ precursor FAs & 4 & 2.36 & 0.078 \\
\hline \multicolumn{4}{|l|}{ Sea urchins } \\
\hline \% lipid & 36 & 2.63 & $0.012^{*}$ \\
\hline $16: 3 n-3$ & 17 & 4.60 & $0.000^{*}$ \\
\hline $18: 3 n-3$ & 20 & 4.26 & $0.000^{*}$ \\
\hline $18: 4 n-3$ & 31 & -2.03 & 0.052 \\
\hline $20: 4 n-6$ & 36 & -3.98 & $0.000^{*}$ \\
\hline$\Sigma$ precursor FAs & 26 & -0.70 & 0.492 \\
\hline$\Sigma$ sea urchin-synthesized FAs & 36 & 5.57 & $0.000^{*}$ \\
\hline \multicolumn{4}{|l|}{ Green crabs } \\
\hline$\%$ lipid & 32 & 1.32 & 0.196 \\
\hline $16: 3 n-3$ & 22 & 3.25 & $0.004^{*}$ \\
\hline $18: 3 n-3$ & 32 & 6.87 & $0.000^{*}$ \\
\hline $18: 4 n-3$ & 32 & 1.09 & 0.285 \\
\hline $20: 4 n-6$ & 32 & -1.37 & 0.179 \\
\hline \multicolumn{4}{|l|}{ Rock crabs } \\
\hline \% lipid & 39 & -0.60 & 0.549 \\
\hline $16: 3 n-3$ & 37 & 2.41 & 0.021 \\
\hline $18: 3 n-3$ & 27 & 3.46 & $0.002 *$ \\
\hline $18: 4 n-3$ & 37 & 0.46 & 0.647 \\
\hline $20: 4 n-6$ & 37 & -0.82 & 0.415 \\
\hline
\end{tabular}




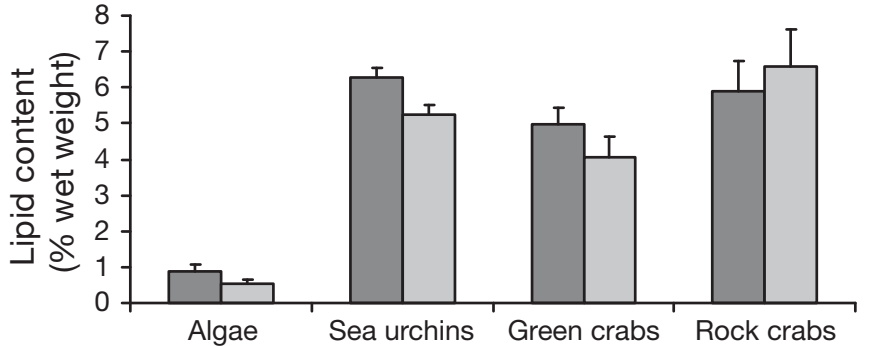

Fig. 1. Lipid content (\% wet weight $+\mathrm{SE}$ ) of algae (Codium fragile ssp. tomentosoides and Saccharina longicruris), sea urchin Strongylocentrotus droebachiensis gonads and green crab Carcinus maenas and rock crab Cancer irroratus hepatopancreases. Dark grey bars represent organisms whose source of primary production was $C$. fragile (i.e. C. fragile, sea urchins fed C. fragile and crabs fed gonads of sea urchins fed C. fragile). Light grey bars represent organisms whose source of primary production was $S$. longicruris a significantly higher proportion of markers 18:4n-3 and 20:4n-6 (Table 1, Fig. 3).

Gonad lipid content of sea urchins fed Codium fragile was significantly higher than that of sea urchins fed Saccharina longicruris (Table 1, Fig. 1). Sea urchins consumed $C$. fragile at a significantly greater rate than S. longicruris: from 11 June to 22 August 2007, mean \pm SE consumption rates per sea urchin (calculated on a per aquarium basis, $\mathrm{n}=4$ per algal diet) were $1.53 \pm$ $0.07 \mathrm{~g} \mathrm{~d}^{-1}$ on $C$. fragile and $1.09 \pm 0.08 \mathrm{~g} \mathrm{~d}^{-1}$ on $S$. longicruris. Algal species and time both had significant effects on consumption rate $(p=0.011$ and 0.004 , respectively) but there was no significant interaction $(\mathrm{p}=0.568)$.

Gonad FA composition differed significantly between sea urchins fed Codium fragile and those fed Saccharina longicruris in both the 75 (ANOSIM, p < 0.001 ) and 19001 tanks (ANOSIM, p = 0.029), and sampling date was non-significant for each diet and tank size ( $p>0.05)$; therefore, data were pooled for further analyses. Withingroup Bray-Curtis similarity was $88 \%$ for both sea urchins fed $C$. fragile and those fed $S$. longicruris. Betweengroup dissimilarity was $14 \%$ for sea urchins on the 2 algal diets.

All FAs present in algae were also present in both groups of sea urchins. The marker FAs identified as more abundant in Codium fragile, 16:3n-3 and 18:3n-3, were also more abundant in gonads of sea urchins fed $C$. fragile than in gonads of those fed Saccharina longicruris (Table 1, Fig. 3). Of the marker FAs identified as more abundant in $S$. longicruris, 20:4n-6 and $18: 4 n-3$ were more abundant in gonads of sea urchins fed $S$. longicruris, although 18:4n-3 was marginally non-significant (Table 1, Fig. 3).

Of the precursor FAs $(16: 0,18: 0$, $16: 1 n-7,18: 1 n-9,18: 2 n-6$ and 18:3n-3), all were significantly more abundant in algae than in sea urchins, except for 16:1n-7, which was more abundant in sea urchins (Table 2, Fig. 4). The source of primary production (i.e. Codium fragile or Saccharina longicruris) was a significant factor for 18:0 (although this was marginally non-significant after Bonferroni correction), 18:1n-9 and 18:2n-6, which were more abundant in S. longicruris, and for 16:0 and 18:3n-3, which were more abundant in C. fragile (Table 2, Fig. 4). The
Fig. 2. Three-dimensional multidimensional scaling (MDS) plot of Bray-Curtis similarities of fatty acid compositions of organisms with either Codium fragile ssp. tomentosoides (O) or Saccharina longicruris (๑) as the source of primary production. 3-D stress values are (a) 0.01, (b) 0.1, (c) 0.03 and (d) 0.05, respectively 

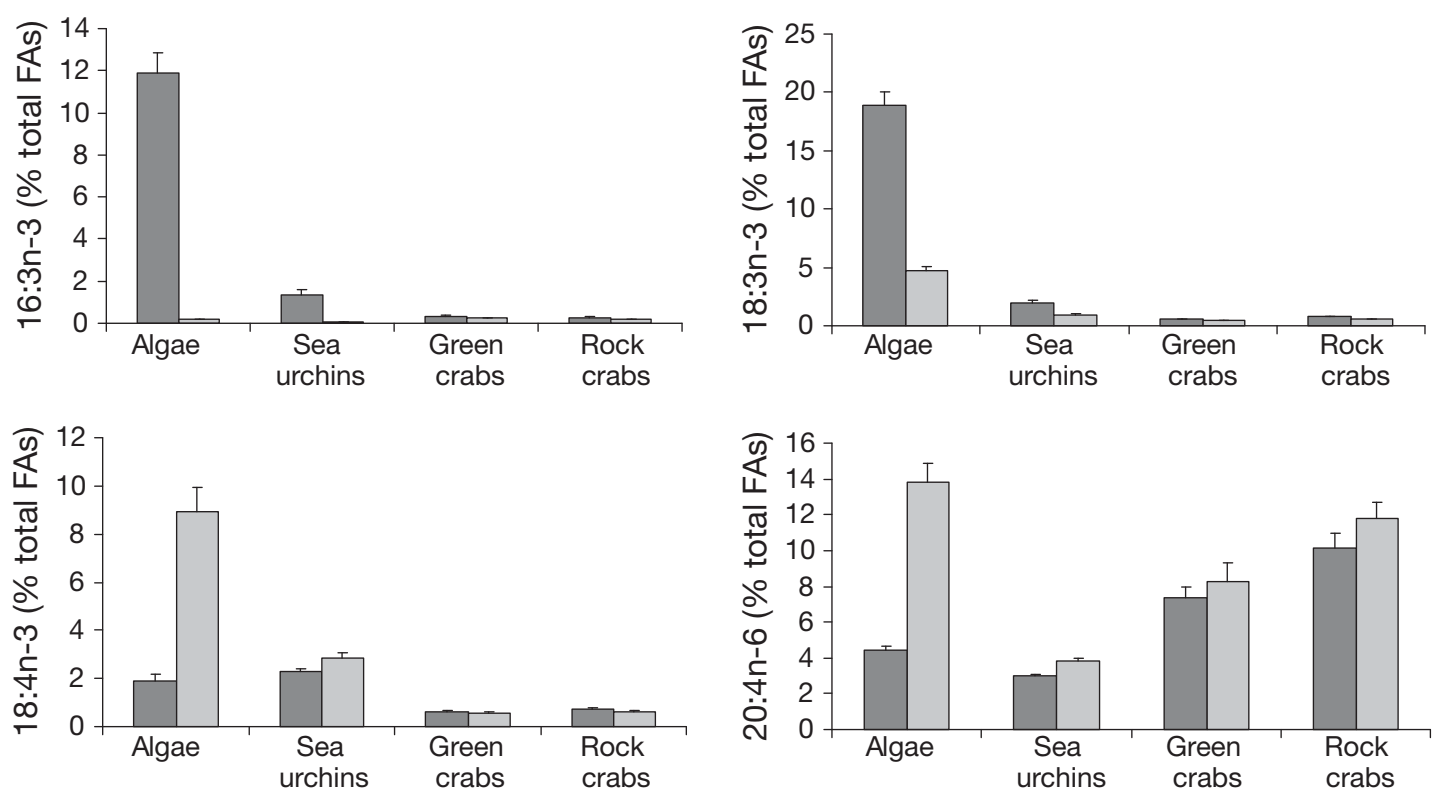

Fig. 3. Abundance of selected marker fatty acids (FAs) (as \% total FAs + SE) in algae (Codium fragile ssp. tomentosoides and Saccharina longicruris), sea urchin Strongylocentrotus droebachiensis gonads, and green crab Carcinus maenas and rock crab Cancer irroratus hepatopancreases. Dark grey bars represent organisms whose source of primary production was $C$. fragile (i.e. C. fragile, sea urchins fed C. fragile and crabs fed gonads of sea urchins fed C. fragile). Light grey bars represent organisms whose source of primary production was $S$. longicruris

Table 2. Results of 2-way ANOVAs on relative abundance of selected fatty acids (FA) in organisms in the experimental food web with trophic level (primary producer [ $1^{\circ}$ producer], primary consumer or secondary consumer) and source of primary production at food web base (Codium fragile ssp. tomentosoides or Saccharina longicruris) as fixed factors. * Significant following Bonferroni correction (experimentwise $\alpha=0.05$ )

\begin{tabular}{|c|c|c|c|c|c|c|}
\hline \multirow[t]{2}{*}{ Source of variation } & \multicolumn{2}{|c|}{$\begin{array}{c}\text { Algae vs. sea } \\
\text { urchins }\end{array}$} & \multicolumn{2}{|c|}{$\begin{array}{l}\text { Sea urchins vs. } \\
\text { Green crabs }\end{array}$} & \multicolumn{2}{|c|}{$\begin{array}{l}\text { Sea urchins vs. } \\
\text { Rock crabs }\end{array}$} \\
\hline & $F_{1,45}$ & $\mathrm{p}$ & $F_{1,68}$ & $\mathrm{p}$ & $F_{1,73}$ & $\mathrm{p}$ \\
\hline \multicolumn{7}{|l|}{$16: 0$} \\
\hline Trophic level & 103.45 & $0.000^{*}$ & 180.86 & $0.000^{*}$ & 133.97 & $0.000^{*}$ \\
\hline $1^{\circ}$ producer & 12.98 & $0.001^{*}$ & 2.15 & 0.147 & 0.91 & 0.343 \\
\hline Trophic level $\times 1^{\circ}$ producer & 22.27 & $0.000^{*}$ & 0.72 & 0.398 & 0.89 & 0.350 \\
\hline \multicolumn{7}{|l|}{$16: 1 n-7$} \\
\hline Trophic level & 27.59 & $0.000^{*}$ & 60.75 & $0.000^{*}$ & 14.50 & $0.000^{*}$ \\
\hline $1^{\circ}$ producer & 0.82 & 0.370 & 0.86 & 0.356 & 0.19 & 0.664 \\
\hline Trophic level $\times 1^{\circ}$ producer & 0.38 & 0.543 & 3.37 & 0.071 & 1.95 & 0.167 \\
\hline \multicolumn{7}{|l|}{ 18:0 } \\
\hline Trophic level & 112.77 & $0.000^{*}$ & 111.40 & $0.000^{*}$ & 235.32 & $0.000^{*}$ \\
\hline $1^{\circ}$ producer & 7.22 & 0.010 & 0.28 & 0.596 & 1.30 & 0.258 \\
\hline Trophic level $\times 1^{\circ}$ producer & 19.71 & $0.000^{*}$ & 4.05 & 0.048 & 1.68 & 0.199 \\
\hline \multicolumn{7}{|l|}{$18: 1 n-9$} \\
\hline Trophic level & 100.70 & $0.000^{*}$ & 186.50 & $0.000^{*}$ & 100.99 & $0.000^{*}$ \\
\hline $1^{\circ}$ producer & 25.38 & $0.000^{*}$ & 5.16 & 0.026 & 0.58 & 0.450 \\
\hline Trophic level $\times 1^{\circ}$ producer & 21.15 & $0.000^{*}$ & 0.82 & 0.369 & 0.06 & 0.810 \\
\hline \multicolumn{7}{|l|}{$18: 2 n-6$} \\
\hline Trophic level & 1171.46 & $0.000^{*}$ & 5.73 & 0.019 & 0.31 & 0.581 \\
\hline $1^{\circ}$ producer & 90.27 & $0.000^{*}$ & 0.48 & 0.493 & 0.80 & 0.376 \\
\hline Trophic level $\times 1^{\circ}$ producer & 82.57 & $0.000^{*}$ & 0.20 & 0.653 & 0.12 & 0.728 \\
\hline \multicolumn{7}{|l|}{$18: 3 n-3$} \\
\hline Trophic level & 852.08 & $0.000^{*}$ & 48.03 & $0.000^{*}$ & 73.97 & $0.000^{*}$ \\
\hline $1^{\circ}$ producer & 455.67 & $0.000^{*}$ & 25.64 & $0.000^{*}$ & 26.09 & $0.000^{*}$ \\
\hline Trophic level $\times 1^{\circ}$ producer & 346.34 & $0.000^{*}$ & 10.75 & $0.002^{*}$ & 13.88 & $0.000^{*}$ \\
\hline
\end{tabular}



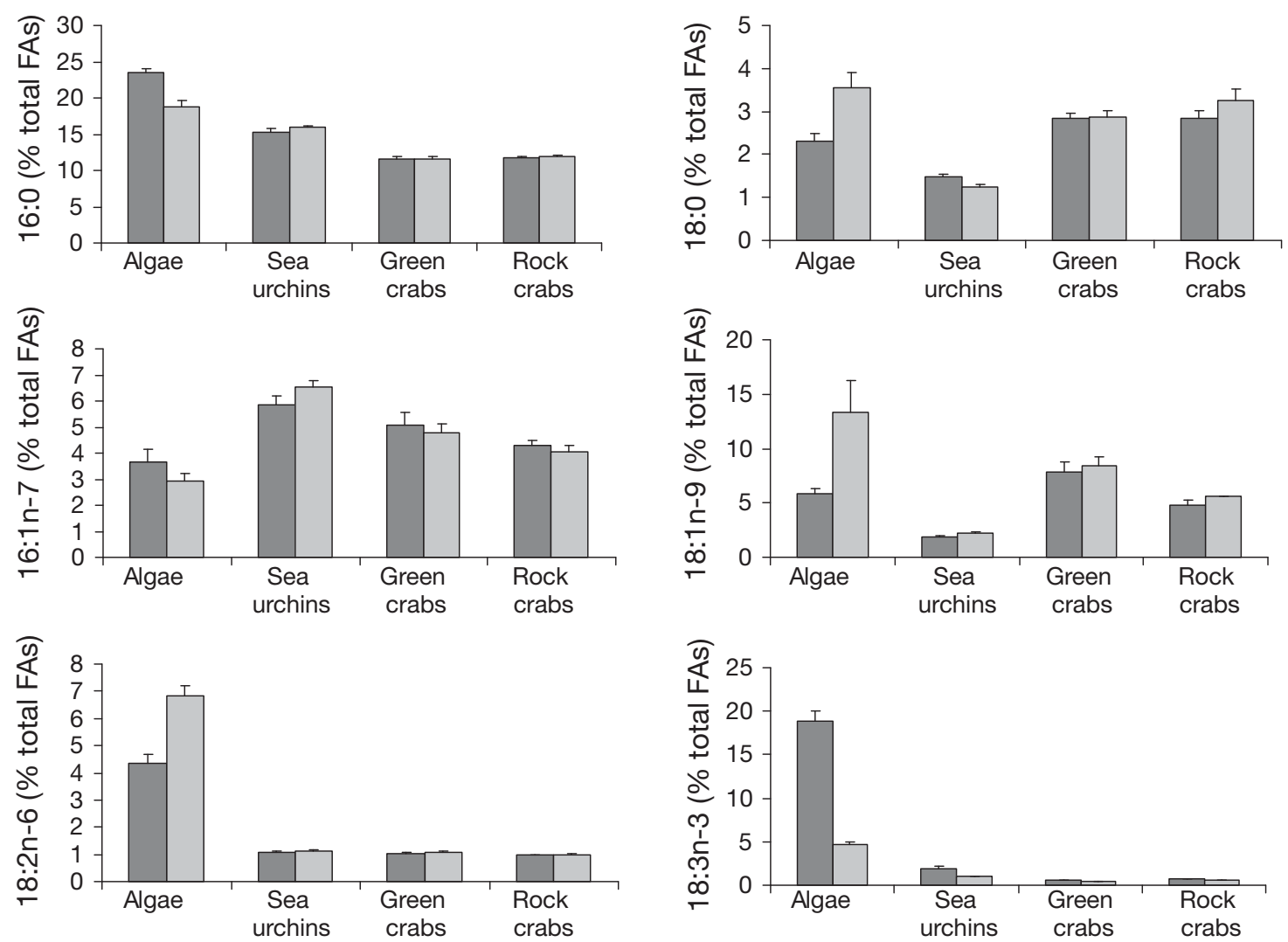

Fig. 4. Abundance of selected precursor fatty acids (FAs) (as \% total FAs + SE) in algae (Codium fragile ssp. tomentosoides and Saccharina longicruris), sea urchin Strongylocentrotus droebachiensis gonads, and green crab Carcinus maenas and rock crab Cancer irroratus hepatopancreases. Dark grey bars represent organisms whose source of primary production was $C$. fragile (i.e. C. fragile, sea urchins fed $C$. fragile and crabs fed gonads of sea urchins fed C. fragile). Light grey bars represent organisms whose source of primary production was $S$. longicruris

interactive effect of primary production source and trophic level was significant for all precursor FAs except 16:1n-7 (Table 2). These precursor FAs comprised a greater proportion of the total FAs in C. fragile $(58.5 \pm 0.8 \%)$ than in $S$. longicruris $(52.2 \pm 3.0 \% \mathrm{SE})$, although this difference was marginally non-significant (Table 1).

Twenty-five additional FAs were present in sea urchin gonads but either absent from algae or present only in trace amounts (mean $<0.10 \%$ ), including 18 -carbon PUFAs, 20-, 22- and 24-carbon monounsaturates, 20:2 and 22:2 NMI dienes, 21:1 and certain omega-3 and omega6 PUFAs (Table 3). These FAs comprised a greater proportion of total FAs in sea urchins fed Codium fragile $(32.5 \pm 0.5 \%)$ than in sea urchins fed Saccharina longicruris $(28.3 \pm 0.9 \%)$ (Table 1$)$.

The hepatopancreas of rock crabs contained slightly more lipid than that of the green crabs $(p=0.057)$, but there was no effect of diet on hepatopancreas lipid content $(p=0.915)$ and no interaction between crab species and diet $(p=0.333$; Fig. 1). FA composition of green crabs differed significantly between diet treat- ments ( $p=0.031$; Fig. 2 c); average Bray-Curtis dissimilarity between individuals in the 2 diet treatments was $15 \%$. There was no effect of diet on overall FA composition of rock crabs ( $p=0.7$; Fig. $2 d)$; average BrayCurtis dissimilarity between individuals in the 2 diet treatments was $20.2 \%$.

All FAs present in sea urchin gonads were also present in the hepatopancreas of both crab species, and no additional FAs were detected in crab hepatopancreas tissues. Of the marker FAs identified in algae and sea urchins, the Codium fragile marker 18:3n-3 was significantly more abundant in crabs of both species in C. fragile food chains, and 16:3n-3 was significantly more abundant in green crabs in the $C$. fragile food chain than those in the Saccharina longicruris food chain (Table 1, Fig. 3). The relative abundance of markers identified for $S$. longicruris (18:4n-3 and 20:4n-6) was not affected by diet for crabs of either species (Table 1, Fig. 3). The precursor FAs 16:0, 16:1n-7 and 18:3n-3 were significantly more abundant in sea urchins than in either crab species, while $18: 0$ and $18: 1 n-9$ were significantly more abundant in crabs than in sea urchins (Table 2, Fig. 4). 
Table 3. Relative fatty acid (FA) composition of organisms in experimental food web: macroalgae (Codium fragile ssp. tomentosoides and Saccharina longicruris), sea urchin Strongylocentrotus droebachiensis gonads, and green crab Carcinus maenas and rock crab Cancer irroratus hepatopancreases. FA values are mean $( \pm \mathrm{SE}) \%$ of total FAs with overall mean concentration $\geq 0.1 \%$

\begin{tabular}{|c|c|c|c|c|c|c|c|c|}
\hline \multirow[b]{2}{*}{$\mathrm{n}$} & \multicolumn{2}{|c|}{- Algae -} & \multicolumn{2}{|c|}{ Sea urchin } & \multicolumn{2}{|c|}{${ }_{\text {Green }} \mathrm{crab}-$} & \multicolumn{2}{|c|}{${ }_{-}$Rock crab } \\
\hline & $\begin{array}{c}\text { C. fragile } \\
5\end{array}$ & S. longicruris & $\begin{array}{c}\text { C. fragile } \\
18\end{array}$ & $\begin{array}{c}\text { S. longicruris } \\
20\end{array}$ & $\begin{array}{c}\text { C. fragile } \\
16\end{array}$ & $\begin{array}{c}\text { S. longicruris } \\
18\end{array}$ & $\begin{array}{c}\text { C. fragile } \\
20\end{array}$ & $\begin{array}{c}\text { S. longicruris } \\
19\end{array}$ \\
\hline $12: 0$ & $35 \pm 0.055$ & $0.19 \pm 0.023$ & $.04 \pm 0.011$ & $0.04 \pm 0.012$ & $0.02 \pm 0.007$ & $0.02 \pm 0.020$ & $0.07 \pm 0.031$ & $0.07 \pm 0.041$ \\
\hline $13: 0$ & $0.01 \pm 0.005$ & $0.01 \pm 0.008$ & $0.05 \pm 0.041$ & $0.04 \pm 0.029$ & $0.03 \pm 0.014$ & $0.02 \pm 0.013$ & 0.028 & 0.03 \\
\hline $14: 0$ & $1.45 \pm 0.084$ & $7.52 \pm 0.614$ & $10.39 \pm 1.555$ & $14.23 \pm 2.979$ & $3.73 \pm 1.388$ & $3.45 \pm 1.890$ & $3.41 \pm 1.703$ & $3.59 \pm 1.378$ \\
\hline $14: 1 \mathrm{n}-9$ & $0.07 \pm 0.020$ & $0.04 \pm 0.008$ & $0.13 \pm 0.021$ & $0.15 \pm 0.038$ & $0.05 \pm 0.030$ & $0.06 \pm 0.036$ & $0.12 \pm 0.070$ & $0.10 \pm 0.054$ \\
\hline $14: 1 \mathrm{n}-5$ & $1.14 \pm 0.281$ & $0.09 \pm 0.027$ & $0.95 \pm 0.279$ & $1.59 \pm 0.693$ & $0.28 \pm 0.136$ & $0.26 \pm 0.179$ & $0.22 \pm 0.155$ & $0.24 \pm 0.137$ \\
\hline iso15:0 & $0.22 \pm 0.008$ & $0.06 \pm 0.013$ & $0.21 \pm 0.079$ & $0.14 \pm 0.051$ & $0.13 \pm 0.037$ & $0.10 \pm 0.035$ & $0.20 \pm 0.090$ & $0.17 \pm 0.086$ \\
\hline $15: 0$ & $0.13 \pm 0.001$ & $0.28 \pm 0.022$ & $0.49 \pm 0.128$ & $0.37 \pm 0.104$ & $0.37 \pm 0.092$ & $0.32 \pm 0.072$ & $0.38 \pm 0.101$ & $0.34 \pm 0.108$ \\
\hline iso16:0 & $0.06 \pm 0.004$ & $0.01 \pm 0.005$ & $0.05 \pm 0.042$ & $0.05 \pm 0.019$ & $0.53 \pm 0.424$ & $0.71 \pm 0.383$ & $0.48 \pm 0.575$ & $0.51 \pm 0.431$ \\
\hline 16:0 & $23.49 \pm 0.553$ & $18.77 \pm 0.959$ & $15.31 \pm 1.680$ & $15.97 \pm 1.117$ & $11.71 \pm 0.809$ & $11.89 \pm 1.021$ & $11.59 \pm 1.330$ & $11.60 \pm 1.801$ \\
\hline $16: 1 \mathrm{n}-11$ & $4.78 \pm 0.767$ & $1.30 \pm 0.192$ & $0.41 \pm 0.139$ & $0.21 \pm 0.047$ & $0.21 \pm 0.066$ & $0.17 \pm 0.050$ & $0.26 \pm 0.117$ & $0.26 \pm 0.150$ \\
\hline $16: 1 n-9$ & $0.33 \pm 0.031$ & $0.12 \pm 0.027$ & $0.32 \pm 0.046$ & $0.24 \pm 0.041$ & $0.24 \pm 0.045$ & $0.24 \pm 0.074$ & $0.23 \pm 0.054$ & 0.22 \\
\hline $16: 1 \mathrm{n}-7$ & $3.66 \pm 0.471$ & $2.92 \pm 0.319$ & $5.84 \pm 1.429$ & $6.55 \pm 1.033$ & $4.30 \pm 0.709$ & $4.07 \pm 1.046$ & $5.09 \pm 2.063$ & 4.77 \\
\hline $16: 1 n-5$ & $0.18 \pm 0.007$ & $0.27 \pm 0.045$ & $2.91 \pm 0.648$ & $3.23 \pm 0.674$ & $1.42 \pm 0.412$ & $1.30 \pm 0.466$ & $0.97 \pm 0.475$ & $0.98 \pm 0.432$ \\
\hline iso17:0 & $0.78 \pm 0.133$ & $0.02 \pm 0.004$ & $0.04 \pm 0.020$ & $0.04 \pm 0.022$ & $0.16 \pm 0.098$ & $0.17 \pm 0.112$ & $0.30 \pm 0.251$ & $0.24 \pm 0.128$ \\
\hline $16: 3 n-6$ & $0.09 \pm 0.018$ & $0.20 \pm 0.022$ & $0.44 \pm 0.153$ & $0.38 \pm 0.129$ & $0.14 \pm 0.075$ & $0.09 \pm 0.074$ & $0.12 \pm 0.065$ & $0.11 \pm 0.060$ \\
\hline $17: 0$ & $0.13 \pm 0.012$ & $0.14 \pm 0.008$ & $0.10 \pm 0.030$ & $0.07 \pm 0.026$ & $0.20 \pm 0.057$ & $0.21 \pm 0.066$ & $0.23 \pm 0.103$ & $0.22 \pm 0.086$ \\
\hline $16: 3 n-4$ & $0.11 \pm 0.022$ & $0.16 \pm 0.031$ & $0.29 \pm 0.127$ & $0.23 \pm 0.066$ & $0.06 \pm 0.034$ & $0.06 \pm 0.035$ & $0.07 \pm 0.038$ & $0.07 \pm 0.038$ \\
\hline $16.3 n-3$ & $11.91 \pm 0.957$ & $0.12 \pm 0.015$ & $1.35 \pm 1.167$ & $0.09 \pm 0.017$ & $0.28 \pm 0.115$ & $0.17 \pm 0.060$ & $0.34 \pm 0.132$ & $0.25 \pm 0.115$ \\
\hline $16: 4 n-3$ & $0.11 \pm 0.033$ & $0.00 \pm 0.001$ & $0.11 \pm 0.034$ & $0.08 \pm 0.038$ & $1.69 \pm 0.982$ & $2.14 \pm 1.169$ & $1.42 \pm 1.068$ & $1.50 \pm$ \\
\hline $16: 4 n-1$ & $0.05 \pm 0.027$ & $0.26 \pm 0.049$ & $1.07 \pm 0.441$ & $0.88 \pm 0.357$ & $0.21 \pm 0.075$ & $0.20 \pm 0.079$ & 0.085 & 106 \\
\hline $18: 0$ & $2.32 \pm 0.175$ & $3.54 \pm 0.377$ & $1.49 \pm 0.196$ & $1.25 \pm 0.209$ & $2.85 \pm 0.666$ & $3.26 \pm 1.161$ & $2.85 \pm 0.564$ & $2.87=$ \\
\hline $18: 1 n-13$ & $0.11 \pm 0.006$ & $0.01 \pm 0.002$ & $0.46 \pm 0.077$ & $0.42 \pm 0.105$ & $0.52 \pm 0.102$ & $0.48 \pm 0.121$ & $0.66 \pm 0.296$ & $0.71 \pm 0.381$ \\
\hline $18: 1 n-9$ & $5.79 \pm 0.477$ & $13.36 \pm 2.944$ & $1.90 \pm 0.320$ & $2.22 \pm 0.348$ & $4.84 \pm 1.642$ & $5.57 \pm 1.087$ & $7.87 \pm 3.291$ & $8.48=$ \\
\hline $18: 1 n-7$ & $1.33 \pm 0.063$ & $0.56 \pm 0.162$ & $3.87 \pm 0.485$ & $3.72 \pm 0.600$ & $4.17 \pm 0.356$ & $4.41 \pm 0.324$ & $6.42 \pm 1.789$ & $6.60 \pm 2.076$ \\
\hline $18: 1 n-5$ & $0.18 \pm 0.016$ & $0.24 \pm 0.068$ & $0.25 \pm 0.043$ & $0.26 \pm 0.073$ & $0.39 \pm 0.052$ & $0.42 \pm 0.051$ & $0.51 \pm 0.118$ & $0.55 \pm 0.098$ \\
\hline $18.2 n-7$ & $0.06 \pm 0.009$ & $0.09 \pm 0.010$ & $1.05 \pm 0.512$ & $0.99 \pm 0.352$ & $0.72 \pm 0.142$ & $0.69 \pm 0.152$ & $0.48 \pm 0.198$ & $0.52 \pm 0.199$ \\
\hline $18: 2 n-6$ & $4.37 \pm 0.295$ & $6.82 \pm 0.366$ & $1.06 \pm 0.199$ & $1.11 \pm 0.222$ & $0.97 \pm 0.140$ & $0.98 \pm 0.227$ & $1.05 \pm 0.122$ & $1.07 \pm 0.175$ \\
\hline $18: 2 n-4$ & $0.01 \pm 0.007$ & $0.06 \pm 0.007$ & $0.23 \pm 0.069$ & $0.19 \pm 0.060$ & $0.20 \pm 0.027$ & $0.18 \pm 0.023$ & $0.21=$ & $0.21 \pm$ \\
\hline $18: 3 n-6$ & $1.48 \pm 0.108$ & $1.01 \pm 0.112$ & $0.44 \pm 0.080$ & $0.38 \pm 0.059$ & $0.19 \pm 0.061$ & $0.14 \pm 0.070$ & \pm 0.086 & 0.15 \\
\hline $18: 3 n-4$ & $0.02 \pm 0.004$ & $0.06 \pm 0.005$ & $0.20 \pm 0.053$ & $0.16 \pm 0.038$ & $0.23 \pm 0.046$ & $0.23 \pm 0.047$ & $0.19 \pm 0.055$ & $0.20 \pm 0.044$ \\
\hline $18: 3 n-3$ & $18.89 \pm 1.136$ & $4.72 \pm 0.298$ & $1.94 \pm 0.928$ & $0.97 \pm 0.286$ & $0.75 \pm 0.088$ & $0.54 \pm 0.088$ & $0.58 \pm 0.189$ & $0.43 \pm 0.083$ \\
\hline $18.4 n-3$ & $1.88 \pm 0.306$ & $8.93 \pm 1.026$ & $2.28 \pm 0.591$ & $2.83 \pm$ & $0.73 \pm$ & $0.61 \pm 0.353$ & $0.62 \pm 0.334$ & 0.57 \\
\hline $18: 4 n-1$ & $0.01 \pm 0.004$ & $0.07 \pm 0.007$ & $0.27 \pm 0.122$ & $0.26 \pm 0.107$ & $0.13 \pm 0.074$ & $0.14 \pm 0.050$ & $0.10 \pm 0.045$ & $0.12 \pm 0.053$ \\
\hline $20: 0$ & $1.02 \pm 0.153$ & $0.63 \pm 0.090$ & $0.64 \pm 0.199$ & $0.49 \pm 0.167$ & $0.45 \pm 0.064$ & $0.40 \pm 0.042$ & $0.47 \pm 0.164$ & $0.42 \pm 0.121$ \\
\hline $20: 1 n-15$ & $0.04 \pm 0.011$ & $0.01 \pm 0.005$ & $4.25 \pm 0.607$ & $3.56 \pm 0.844$ & $4.59 \pm 1.141$ & $3.54 \pm 1.053$ & $3.40 \pm 1.887$ & $2.91 \pm 1.537$ \\
\hline $20: 1 n-11$ & $0.10 \pm 0.007$ & $0.09 \pm 0.016$ & $0.67 \pm 0.184$ & $0.50 \pm 0.137$ & $0.70 \pm 0.201$ & $0.63 \pm 0.211$ & $1.31 \pm 0.864$ & $1.37 \pm 0.684$ \\
\hline $20: 1 n-9$ & $0.03 \pm 0.000$ & $0.01 \pm 0.003$ & $4.32 \pm 0.873$ & $4.22 \pm 0.829$ & $4.14 \pm 0.781$ & $3.95 \pm 0.819$ & 1.553 & $3.99=$ \\
\hline $20: 1 n-7$ & $0.00 \pm 0.002$ & $0.00 \pm 0.000$ & $3.70 \pm$ & $3.47 \pm$ & $3.29 \pm$ & 2. & 256 & 3.24 \\
\hline $20: 2 \Delta 5,11$ & $0.01 \pm 0.004$ & $0.00 \pm 0.000$ & $3.89 \pm 0.637$ & $3.51 \pm 0.771$ & $2.82 \pm 0.681$ & $2.46 \pm 0.748$ & $1.82 \pm 1.027$ & $1.77 \pm 0.954$ \\
\hline $20: 2 \Delta 5,13$ & $0.00 \pm 0.000$ & $0.00 \pm 0.000$ & $2.67 \pm 0.820$ & $2.45 \pm 0.706$ & $2.21 \pm 0.591$ & $1.73 \pm 0.529$ & $1.65 \pm 0.726$ & $1.56 \pm 0.648$ \\
\hline $20: 2 n-9$ & $0.33 \pm 0.027$ & $0.00 \pm 0.000$ & $0.18 \pm 0.076$ & $0.19 \pm 0.050$ & $0.25 \pm 0.059$ & $0.25 \pm 0.033$ & $0.22 \pm 0.095$ & $0.22 \pm 0.100$ \\
\hline $20: 1^{a}$ & $0.00 \pm 0.000$ & $0.00 \pm 0.000$ & $0.39 \pm 0.148$ & $0.50 \pm 0.226$ & $0.27 \pm 0.083$ & $0.32 \pm 0.074$ & $0.19 \pm 0.104$ & $0.25 \pm 0.142$ \\
\hline $20: 2 n-6$ & $0.05 \pm 0.001$ & $0.09 \pm 0.006$ & $0.91 \pm 0.227$ & $0.86 \pm 0.231$ & $1.89 \pm 0.278$ & $1.94 \pm 0.449$ & $2.34 \pm 0.648$ & $2.43 \pm 0.861$ \\
\hline $20: 3 n-6$ & $0.26 \pm 0.017$ & $0.70 \pm 0.136$ & $0.65 \pm 0.075$ & $0.70 \pm 0.136$ & $0.61 \pm 0.059$ & $0.63 \pm 0.076$ & $0.60 \pm 0.205$ & $0.65 \pm 0.198$ \\
\hline $20: 4 n-6$ & $4.45 \pm 0.233$ & $13.83 \pm 1.009$ & $2.97 \pm 0.575$ & $3.81 \pm 0.708$ & $10.12 \pm 3.311$ & $11.82 \pm 3.838$ & $7.32 \pm 2.920$ & $8.30 \pm 4.303$ \\
\hline $20: 0$ cyc $^{b}$ & $0.00 \pm 0.000$ & $0.03 \pm 0.012$ & $1.48 \pm 0.181$ & $1.30 \pm 0.352$ & $1.31 \pm 0.385$ & $0.95 \pm 0.353$ & $1.09 \pm 0.596$ & $0.91 \pm 0.526$ \\
\hline $20: 3 n-3$ & $0.10 \pm 0.009$ & $0.02 \pm 0.013$ & $1.42 \pm 0.683$ & $0.69 \pm$ & $1.02 \pm 0$ & $0.75=$ & 238 & $0.77 \pm$ \\
\hline $20: 4 n-3$ & $0.24 \pm 0.037$ & $0.73 \pm 0.075$ & $0.89 \pm 0.236$ & $0.88 \pm 0.302$ & $0.54 \pm 0.165$ & $0.56 \pm 0.078$ & $0.51 \pm 0.124$ & $0.54 \pm 0.263$ \\
\hline $20: 5 n-3$ & $5.35 \pm 0.682$ & $11.81 \pm 0.741$ & $7.87 \pm 2.085$ & $7.86 \pm 1.506$ & $15.01 \pm 3.273$ & $16.12 \pm 3.980$ & $12.33 \pm 2.738$ & $12.41 \pm 2.916$ \\
\hline $22: 1 n-11$ & $0.12 \pm 0.048$ & $0.01 \pm 0.004$ & $0.14 \pm 0.040$ & $0.10 \pm 0.045$ & $0.30 \pm 0.418$ & $0.22 \pm 0.214$ & $0.56 \pm 0.475$ & $0.67 \pm 0.712$ \\
\hline $22: 1 n-9$ & $0.07 \pm 0.036$ & $0.00 \pm 0.000$ & $2.79 \pm 0.647$ & $2.21 \pm 0.586$ & $2.06 \pm 0.601$ & $1.59 \pm 0.579$ & $2.07 \pm 1.090$ & $1.75 \pm 0.904$ \\
\hline $22: 1 n-7$ & $0.06 \pm 0.013$ & $0.00 \pm 0.000$ & $0.16 \pm 0.044$ & $0.12 \pm 0.037$ & $0.26 \pm 0.038$ & $0.27 \pm 0.089$ & $0.59 \pm 0.297$ & $0.55 \pm 0.211$ \\
\hline $22: 2 \Delta 7,13$ & $0.11 \pm 0.028$ & $0.00 \pm 0.000$ & $0.39 \pm 0.072$ & $0.32 \pm 0.091$ & $0.39 \pm 0.108$ & $0.33 \pm 0.178$ & $0.64 \pm 0.296$ & $0.62 \pm 0.236$ \\
\hline $22: 2 \Delta 7,15$ & $0.01 \pm 0.007$ & $0.00 \pm 0.000$ & $1.28 \pm 0.378$ & $1.11 \pm 0.462$ & $1.46 \pm 0.386$ & $1.06 \pm 0.408$ & $1.52 \pm 0.661$ & $1.26 \pm 0.548$ \\
\hline $21: 5 n-3$ & $0.05 \pm 0.013$ & $0.00 \pm 0.000$ & $0.16 \pm 0.063$ & $0.12 \pm 0.037$ & $0.12 \pm 0.016$ & $0.11 \pm 0.022$ & $0.14 \pm 0.076$ & $0.13 \pm 0.071$ \\
\hline $22: 4 n-6$ & $0.04 \pm 0.003$ & $0.00 \pm 0.000$ & $0.26 \pm 0.072$ & $0.27 \pm 0.054$ & $0.38 \pm 0.034$ & $0.41 \pm 0.074$ & $0.99 \pm 0.908$ & $0.98 \pm 0.637$ \\
\hline $22: 5 n-6$ & $0.14 \pm 0.026$ & $0.00 \pm 0.000$ & $0.27 \pm 0.092$ & $0.17 \pm 0.043$ & $0.23 \pm 0.021$ & $0.23 \pm 0.034$ & $0.28 \pm 0.178$ & $0.25 \pm 0.038$ \\
\hline $22: 5 n-3$ & $0.92 \pm 0.065$ & $0.05 \pm 0.009$ & $0.39 \pm 0.129$ & $0.31 \pm 0.068$ & $0.77 \pm 0.251$ & $0.81 \pm 0.199$ & 0.858 & $1.36 \pm 0.622$ \\
\hline & $0.02 \pm 0.007$ & $.00 \pm 0.000$ & $.25 \pm 0.476$ & $.84 \pm 0.2$ & $2.31 \pm 0.861$ & 0.862 & $2.73 \pm 1.082$ & $2.70 \pm 1.207$ \\
\hline
\end{tabular}




\section{DISCUSSION}

We examined the ability of FA data to distinguish sources of primary production contributing to higher trophic levels in an experimental food web based on 2 algal species (native Saccharina longicruris and invasive Codium fragile), with one primary consumer (sea urchins) and 2 secondary consumers (native rock crabs and invasive green crabs). We found 2 potential markers of $C$. fragile that persisted through both trophic transfers; however, their relative abundance decreased with each transfer, indicating the limited utility of these markers for larger-scale food web studies.

The 2 algal species in the present study, Saccharina longicruris and Codium fragile, were distinct in their FA compositions, and these were similar to the FA compositions reported by Cook et al. (2000) for $S$. longicruris and by Khotimchenko (2003) for C. fragile. We identified 20:4n-6 and 18:4n-3 as potential marker FAs for $S$. longicruris, and $16: 3 n-3$ and $18: 3 n-3$ as potential marker FAs for $C$. fragile. FAs 20:4n-6 and 18:4n-3 are dominant in brown macroalgae and are useful as general markers for the group (Graeve et al. 2002), but would not distinguish $S$. longicruris from other kelps, such as Laminaria digitata, present in the rocky subtidal ecosystem in Atlantic Canada. FA 18:3n-3 is both a major constituent in green macroalgae (Graeve et al. 2002, Khotimchenko 2003) and a precursor for a major highly unsaturated FA (HUFA) synthesis pathway, so its utility in distinguishing $C$. fragile in field studies may be limited. However, significant quantities of 16:3n-3 have been detected only in $C$. fragile and 2 other genera of green algae (Khotimchenko 1995, 2003), making it a potentially useful marker for $C$. fragile.

The higher consumption rate of Codium fragile than Saccharina longicruris by sea urchins has been reported previously (Scheibling \& Anthony 2001, Sumi \& Scheibling 2005, Lyons \& Scheibling 2007a,b) and attributed to compensatory feeding on $C$. fragile because of its lower nutritional quality compared to kelp (Lyons \& Scheibling 2007b). Gonads of sea urchins fed the 2 algal diets differed significantly in their FA composition, although differences between gonads were less pronounced than differences between diets. Sea urchins substantially modify dietary FAs, such that their overall FA composition does not closely resemble that of their diets (Castell et al. 2004, Kelly et al. 2008). The presence of FAs in sea urchin gonads that were absent from their diets indicates that FA biosynthesis occurred in sea urchins on both algal diets (Castell et al. 2004). Many marine organisms have a limited capacity for HUFA biosynthesis, so synthesis of these FAs by sea urchins from precursors in macroalgae may represent an important link in rocky subtidal food webs (Dalsgaard et al. 2003, Hall et al. 2006).
Certain saturated and monounsaturated FAs and the PUFAs 18:2n-6 and 18:3n-3 decreased in relative abundance from algae to sea urchins, likely indicating that these were used as precursors for synthesis of other FAs (Castell et al. 2004). The higher proportion of sea-urchin synthesized FAs found in gonads of sea urchins in the Codium fragile food chain may be a result of a higher proportion of precursor FAs found in C. fragile than in Saccharina longicruris. Data from Castell et al. (2004) support this hypothesis: sea urchins fed artificial diets high in precursor FAs (94 to $96 \%$ of total FAs) had a higher proportion of seaurchin synthesized FAs in their gonads than those fed a similar diet with fewer precursors (55\%) or kelp (34\%).

The source of primary production at the base of the food chain significantly affected overall FA composition of the invasive green crab but not of the native rock crab. Crustaceans generally have a limited ability to synthesize HUFAs such as 20:4n-6 and 20:5n-3 from 18-C precursors such as 18:2n-6 and 18:3n-3 (González-Félix et al. 2002). However, our results show an increase in the relative abundance of these HUFAs between sea urchins and crabs regardless of sea urchin diet or crab species. This suggests that crabs must either synthesize or preferentially retain these HUFAs. The presence of 20:2n-6 in both crab species suggests that dietary $18: 2 \mathrm{n}-6$ is converted to $20: 4 \mathrm{n}-6$, as 20:2n-6 is an intermediate in this metabolic pathway (Merican \& Shim 1996). Further evidence of FA modification by crabs was provided by the lower levels of potential precursor FAs in crabs than in sea urchins.

The persistence of markers for Codium fragile but not Saccharina longicruris in the food web, and the distinct FA compositions of green crabs but not rock crabs on different diets, may be related to the feeding ecology of both sea urchins and crabs. The green sea urchin has evolved to feed on native seaweeds such as $S$. longicruris, and is unaccustomed to consuming the invasive alga $C$. fragile. Desaturase enzymes in the sea urchin may be present in quantities appropriate for native food sources, but insufficient for certain novel food items. Thus $C$. fragile markers in sea urchin tissues may represent the quantity of $16: 3 n-3$ and $18: 3 n-$ 3 in $C$. fragile that exceeds the processing capacity of $\Delta-6$ desaturase in the sea urchin. Similarly, markers present in the invasive green crab may represent FAs in excess of its enzymatic processing capacity, as it does not normally consume sea urchins. Because the rock crab is a natural predator of sea urchins, it may have the enzymatic capacity to process FAs present in sea urchins, resulting in no marker FAs in the kelp food chain and no overall difference between rock crabs on the 2 diets. This pattern merits further research, as it may suggest the utility of FA analysis for 
detecting invasive primary producers at higher trophic levels, and for analyzing the diet of invasive consumers.

Other studies that have traced FA markers through multiple trophic transfers have focused on a food chain with a single source of primary production (Hall et al. 2006, Shin et al. 2008). The present study is one of the few that have compared levels of potential marker FAs between animals on different diets in order to assess their validity as tracers in a particular food web. Our results concur generally with those of Hall et al. (2006) in that we also were able to detect several markers in the first trophic transfer and fewer in the second transfer, and the relative abundance of marker FAs decreased with each trophic transfer. Both Hall et al. (2006) and Shin et al. (2008) found an increase in the relative abundance of 20:4n-6 at each trophic transfer. Our results were similar for the second trophic transfer, indicating either synthesis or selective retention of this FA by both crab species.

We were able to detect Codium fragile as the primary producer using the FA markers for the invasive alga (16:3n-3 and 18:3n-3). Of the 2 markers, $18: 3 n-3$ is less likely to be useful in field studies because it is a general marker for green algae and ubiquitous in marine systems, as well as being a common precursor for FA synthesis (Hall et al. 2006). Signal attenuation is also likely to limit the usefulness of FA markers in this food web, as the magnitude of difference between diets decreased with each trophic transfer. Differences between crab species in the overall effect of diet on their FA composition indicate that the effects of primary producers may vary across consumer taxa, and thus specific food chains of interest should be tested in the laboratory before attempting to use FA analysis in field studies.

Acknowledgements. We thank J. Lindley, D. Lyons, L. Sauchyn, K. Krumhansl and S. Watanabe for their assistance in the field; and S. Al-Shaghay, A. Young and J. Jones for laboratory support. This research was funded by Discovery Grants and Research Tools and Instruments Grants and a Canadian Healthy Oceans Network (CHONe) grant to R.E.S and S.J.I from the Natural Sciences and Engineering Research Council (NSERC) of Canada. J.R.K. was supported by a Dalhousie Scholarship, a Killam Predoctoral Scholarship and a NSERC Canada Graduate Scholarship.

\section{LITERATURE CITED}

Alfaro AC, Thomas F, Sergent L, Duxbury M (2006) Identification of trophic interactions within an estuarine food web (northern New Zealand) using fatty acid biomarkers and stable isotopes. Estuar Coast Shelf Sci 70: 271-286

Budge SM, Iverson SJ, Koopman HN (2006) Studying trophic ecology in marine ecosystems using fatty acids: a primer on analysis and interpretation. Mar Mamm Sci 22:759-801
Castell JD, Kennedy EJ, Robinson SMC, Parsons GJ, Blair TJ, Gonzalez-Duran E (2004) Effect of dietary lipids on fatty acid composition and metabolism in juvenile green sea urchins (Strongylocentrotus droebachiensis). Aquaculture 242:417-435

Chapman AS, Scheibling RE, Chapman ARO (2002) Species introductions and changes in marine vegetation of Atlantic Canada. In: Claudi R, Nantel P, Muckle-Jeffs E (eds) Alien invaders in Canada's waters, wetlands, and forests. Natural Resources Canada, Canadian Forest Service Science Branch, Ottawa, ON, p 133-148

Clarke KR, Gorley RN (2006) PRIMER v6: user manual/tutorial. PRIMER-E, Plymouth

Clarke KR, Warwick RM (1994) Change in marine communities: an approach to statistical analysis and interpretation. Natural Environment Research Council, London

Cook EJ, Bell MV, Black KD, Kelly MS (2000) Fatty acid compositions of gonadal material and diets of the sea urchin, Psammechinus miliaris: trophic and nutritional implications. J Exp Mar Biol Ecol 255:261-274

Dalsgaard J, St. John M, Kattner G, Muller-Navarra D, Hagen W (2003) Fatty acid trophic markers in the pelagic marine environment. Adv Mar Biol 46:225-340

Folch J, Lees M, Sloane Stanley GH (1957) A simple method for the isolation and purification of total lipids from animal tissues. J Biol Chem 226:287-291

> González-Félix ML, Gatlin DM III, Lawrence AL, PerezVelazquez M (2002) Effect of various dietary lipid levels on quantitative essential fatty acid requirements of juvenile Pacific white shrimp Litopenaeus vannamei. J World Aquacult Soc 33:330-340

Graeve M, Kattner G, Hagen W (1994) Diet-induced changes in the fatty-acid composition of Arctic herbivorous copepods: experimental evidence of trophic markers. J Exp Mar Biol Ecol 182:97-110

> Graeve M, Kattner G, Wiencke C, Karsten U (2002) Fatty acid composition of Arctic and Antarctic macroalgae: indicator of phylogenetic and trophic relationships. Mar Ecol Prog Ser 231:67-74

Hall D, Lee SY, Meziane T (2006) Fatty acids as trophic tracers in an experimental estuarine food chain: tracer transfer. J Exp Mar Biol Ecol 336:42-53

> Harris LG, Tyrrell MC (2001) Changing community states in the Gulf of Maine: synergism between invaders, overfishing and climate change. Biol Invasions 3:9-21

> Himmelman JH, Steele DH (1971) Foods and predators of the green sea urchin Strongylocentrotus droebachiensis in Newfoundland waters. Mar Biol 9:315-322

Iverson SJ (1993) Milk secretion in marine mammals in relation to foraging: Can milk fatty acids predict diet? Symp Zool Soc Lond 66:263-291

> Iverson SJ, Frost KJ, Lowry LF (1997) Fatty acid signatures reveal fine scale structure of foraging distribution of harbor seals and their prey in Prince William Sound, Alaska. Mar Ecol Prog Ser 151:255-271

Iverson SJ, Field C, Bowen WD, Blanchard W (2004) Quantitative fatty acid signature analysis: a new method of estimating predator diets. Ecol Monogr 74: 211-235

> Iverson SJ, Springer AM, Kitaysky AS (2007) Seabirds as indicators of food web structure and ecosystem variability: qualitative and quantitative diet analyses using fatty acids. Mar Ecol Prog Ser 352:235-244

> Kelly JR, Scheibling RE, Iverson SJ, Gagnon P (2008) Fatty acid profiles in the gonads of the sea urchin Strongylocentrotus droebachiensis on natural algal diets. Mar Ecol Prog Ser 373:1-9 
Kharlamenko VI, Kiyashko SI, Imbs AB, Vyshkvartzev DI (2001) Identification of food sources of invertebrates from the seagrass Zostera marina community using carbon and sulfur stable isotope ratio and fatty acid analyses. Mar Ecol Prog Ser 220:103-117

Khotimchenko SV (1995) Fatty acid composition of green algae of the genus Caulerpa. Bot Mar 38:509-512

Khotimchenko SV (2003) Fatty acids of species in the genus Codium. Bot Mar 46:456-460

Levin PS, Coyer JA, Petrik R, Good TP (2002) Communitywide effects of nonindigenous species on temperate rocky reefs. Ecology 83:3182-3193

Lyons DA, Scheibling RE (2007a) Differences in somatic and gonadic growth of sea urchins (Strongylocentrotus droebachiensis) fed kelp (Laminaria longicruris) or the invasive alga Codium fragile ssp. tomentosoides are related to energy acquisition. Mar Biol 152:285-295

Lyons DA, Scheibling RE (2007b) Effect of dietary history and algal traits on feeding rate and food preference in the green sea urchin Strongylocentrotus droebachiensis. J Exp Mar Biol Ecol 349:194-204

Lyons DA, Scheibling RE (2008) Context-dependant survival of the invasive seaweed Codium fragile ssp. tomentosoides in kelp bed and urchin barren habitats off Nova Scotia. Aquat Biol 2:17-27

Lyons DA, vanAlstyne K, Scheibling RE (2007) Anti-grazing activity and seasonal variation of dimethylsulfoniopropionate-associated compounds in the invasive alga Codium fragile ssp. tomentosoides. Mar Biol 153:179-188

Meidel SK, Scheibling RE (1998) The annual reproductive cycle of the green sea urchin Strongylocentrotus droebachiensis in differing habitats off Nova Scotia Canada. Mar Biol 131:461-478

Merican ZO, Shim KF (1996) Qualitative requirements of essential fatty acids for juvenile Penaeus monodon. Aquaculture 147:275-291

Meziane T, d'Agata F, Lee SY (2006) Fate of mangrove organic matter along a subtropical estuary: small-scale exportation and contribution to the food of crab communities. Mar Ecol Prog Ser 312:15-27

> Nichols PD, Klumpp DW, Johns RB (1986) Lipid components and utilization in consumers of a seagrass community: an indication of carbon source. Comp Biochem Physiol B Biochem Mol Biol 83:103-113

Prince JS, LeBlanc WG (1992) Comparative feeding preference of Strongylocentrotus droebachiensis (Echinoidea) for the invasive seaweed Codium fragile ssp. tomen-

Editorial responsibility: Laura Airoldi,

Ravenna, Italy tosoides (Chlorophyceae) and four other seaweeds. Mar Biol 113:159-163

Provan J, Booth D, Todd NP, Beatty GE, Maggs CA (2008) Tracking biological invasions in space and time: elucidating the invasive history of the green alga Codium fragile using old DNA. Divers Distrib 14:343-354

> Rooker JR, Turner JP, Holt SA (2006) Trophic ecology of Sargassum-associated fishes in the Gulf of Mexico determined from stable isotopes and fatty acids. Mar Ecol Prog Ser 313:249-259

Sargent JR, Parkes RJ, Mueller-Harvey I, Henderson RJ (1988) Lipid biomarkers in marine ecology. In: Sleigh MA (ed) Microbes in the sea. Ellis Horwood, Chichester, p 119-137

Scheibling RE (1984) Predation by rock crabs (Cancer irroratus) on diseased sea urchins (Strongylocentrotus droebachiensis) in Nova Scotia. Can J Fish Aquat Sci 41: 1847-1851

Scheibling RE (1986) Increased macroalgal abundance following mass mortalities of sea urchins (Strongylocentrotus droebachiensis) along the Atlantic coast of Nova Scotia. Oecologia 68:186-198

Scheibling RE, Anthony SX (2001) Feeding, growth and reproduction of sea urchins (Strongylocentrotus droebachiensis) on single and mixed diets of kelp (Laminaria spp.) and the invasive alga Codium fragile ssp. tomentosoides. Mar Biol 139:139-146

Scheibling RE, Hamm J (1991) Interactions between sea urchins (Strongylocentrotus droebachiensis) and their predators in field and laboratory experiments. Mar Biol 110:105-116

Scheibling RE, Hatcher BG (2007) Ecology of Strongylocentrotus droebachiensis. In: Lawrernce JM (ed) Edible sea urchins: biology and ecology. Elsevier, Amsterdam, p 353-392

> Shin PKS, Yip KM, Xu WZ, Wong WH, Cheung SG (2008) Fatty acid as markers to demonstrating trophic relationships among diatoms, rotifers and green-lipped mussels. J Exp Mar Biol Ecol 357:75-84

Sumi CBT, Scheibling RE (2005) Role of grazing by sea urchins Strongylocentrotus droebachiensis in regulating the invasive alga Codium fragile ssp. tomentosoides in Nova Scotia. Mar Ecol Prog Ser 292:203-212

Wai TC, Ng JSS, Leung KMY, Dudgeon D, Williams GA (2008) The source and fate of organic matter and the significance of detrital pathways in a tropical coastal ecosystem. Limnol Oceanogr 54:1479-1492

Submitted: March 5, 2009; Accepted: July 21, 2009

Proofs received from author(s): September 14, 2009 